\title{
Severe Dysplasia and Spontaneous Uterus Rupture in Labour
}

\author{
Pafumi $C^{2 *}$, Pulvirenti $\mathbf{G}^{1}$, Leanza $\mathrm{V}^{2}$, Leanza $\mathbf{G}^{3}$, lemmola $A^{4}$ and $D^{\prime}$ Agati $A^{2}$
}

${ }^{1}$ Pulmonary Division, G. Gaslini Institute and Pediatric Department, University of Genoa, Genoa, Italy

${ }^{2}$ Obstetrics and Gynaecology Department, Catania University, Catania, Italy

${ }^{3}$ B.R.A.I.N. Centre for Neuroscience, Department of Life Sciences, University of Trieste, Trieste, Italy

${ }^{4}$ Assisted Reproduction Department University of Catania, Italy

\begin{abstract}
The authors report a case of spontaneous uterine rupture in a patient with no risk factor. The break was initially silent and incomplete. Then, because of profuse bleeding was subjected to subtotal hysterectomy and is now in good health. Histological examination revealed severe dysplasia with necrosis of the coating of the esocervix. The authors conclude by stressing the importance of diagnostic assessment of the cervix in pregnancy is to prevent cervical cancer, to eliminate a rare risk factor for uterine rupture during labor.
\end{abstract}

Keywords: Severe Dysplasia; Hysterectomy; Labour; Uterine Rupture

\section{Introduction}

Uterine rupture is potentially life-threatening to both mother and baby. It occurs when the integrity of the myometrial wall is compromised. This usually occurs during the last weeks of pregnancy, labour or delivery. However, damage to the uterus prior to labour is usually in the uterine body while damage during labour is usually in the lower segment. One of the main predisposing factors for uterine rupture is scarring of the uterus due to a previous surgery, namely caesarean sections [1]. A study conducted in 2005 by the World Health Organisation on the worldwide prevalence of uterine rupture resulted in a median of $0.053 \%$ [2]. At present, poor antenatal care, cephalopelvic disproportion, uterine scars and oxitocin administration are considered to be the most important etiopathogenetic factors [3]. Other risk factors to consider are congenital anomalies, age, multiparity and curettages (especially the ones complicated by perforation, fibrosis and/or adenomyosis). Notwithstanding these known factors, a case was reported in 2006 of a prelabour uterine rupture with no apparent risk factors [4].

\section{Case Report}

We report a case of a woman of 39 years, the second pregnancy, with a previous spontaneous birth and a miscarriage who gave birth vaginally to the thirty-ninth weeks gestation. The baby weighed 2800 grams at birth. After spontaneous delivery, the patient began to bleed and was subjected to curettage. Continuing blood loss was decided an hysterectomy. The piece removed showed a continuous solution in the left margin in contours of uterus. Histological examination showed an area of severe dysplasia and necrosis of the esocervix previous to the current pregnancy around the rupture zone that has been, presumably, the "locus minoris resistentiae", as it were a weakness of the uterine wall that carries with it the stress of childbirth led to first a partial rupture and silent of the utero, and thereafter as a result of the hematoma that had come to form, led to a complete rupture of the uterus complete and extended upward. After subtotal hysterectomy she had a normal postoperative course and now is in excellent health.

\section{Discussion}

The peculiarity of this case report is that the uterine rupture was spontaneous and occurred in a patient with no underlying risk factors.

The main causes of uterine rupture in pregnancy related obstetric anamnesis and / or the administration of oxytocin. The main factors are obstetric medical history: previous gynaecological operations on the uterus, previous cesarean sections, scraping due to abortions and their complications. Regarding wing during pregnancy can cause spontaneous rupture of the uterus and silent during labor: fetal macrosomia and abnormal fetal presentation [7]. The patient in question did not involve any of these diseases. She gave birth to term a fetus of 2900 gr. vertex presentation in the left front. It 'was the histological examination revealed a uterus that can cause: severe dysplasia of the esocervix cell necrosis, which probably represented the "locus" from which "minoris resistentiae" started breaking and silent, at first, incomplete' uterus, which then led to a full thickness tear, due to myometrial hematoma that was forming in the meantime. In conclusion this case report we can infer the importance of clinical evaluation and cytologic of the esocervix in pregnancy not only for its neoplastic complications but also because the morphological and functional disorder caused by uterine dysplasias may cause a softening of the tissues that become brittle and susceptible broken.

\section{Acknowledgment}

Valentina Pafumi has carried out English language editing for this article.

\section{References}

1. Schrinsky DC, Benson RC (1978) Rupture of the pregnant uterus: a review. Obstet Gynecol Surv 33: 217-232.

2. Hofmeyr GJ, Say L, Gülmezoglu AM (2005) WHO systematic review of maternal mortality and morbidity: the prevalence of uterine rupture. BJOG 112 : 1221-1228.

3. Ola ER, Olamijulo JA (1988) Rupture of the uterus at the Lagos University Teaching Hospital, Lagos, Nigeria. West Afr J Med 17:188-193.

4. Walsh CA, O'Sullivan RJ, Foley ME (2006) Unexplained prelabor uterine rupture in a term primigravida. Obstet Gynecol 108: 725-727.

*Corresponding author: Pafumi C, Department of Obstetrics and Gynaecology, University of Catania, Italy, E-mail: pafumi@unict.it

Received July 13, 2011; Accepted September 05, 2011; Published November 06, 2011

Citation: Pafumi C, Pulvirenti G, Leanza V, Leanza G, lemmola A, et al. (2011) Severe Dysplasia and Spontaneous Uterus Rupture in Labour. J Clinic Res Bioeth 2:119. doi:10.4172/2155-9627.1000119

Copyright: ( 2011 Pafumi C, et al. This is an open-access article distributed under the terms of the Creative Commons Attribution License, which permits unrestricted use, distribution, and reproduction in any medium, provided the original author and source are credited. 
Citation: Pafumi C, Pulvirenti G, Leanza V, Leanza G, lemmola A, et al. (2011) Severe Dysplasia and Spontaneous Uterus Rupture in Labour. J Clinic Res Bioeth 2:119. doi:10.4172/2155-9627.1000119

Page 2 of 2

5. Nikolov A, Negentsov N, Maĭnkhard K, Mekhandzhiev Ts (2007) Course of pregnancy and delivery in cases with cervical deciduosis. Akush Ginekol (Sofiia) 46: 3-7.

6. Larsson G, Grundsell H, Gullberg B, Svennerud S (1982) Outcome of pregnancy after conisation. S. Acta Obstet Gynecol Scand 61: 461-466.

7. Schrinsky DC, Benson RC (1978) Rupture of the pregnant uterus: a review. Obstet Gynecol Surv 33: 217-232
8. Fatfouta I, Villeroy de Galhau S, Dietsch J, Eicher E, Perrin D (2008) Spontaneous uterine rupture of an unscarred uterus during labor: case report and review of the literature. J Gynecol Obstet Biol Reprod (Paris) 37: 200-203

9. Pafumi C, Farina M, Pernicone G, Russo A, Bandiera S, et al. (2001) Adenomyosis and uterus rupture during labor. Zhonghua Yi Xue Za Zhi (Taipei) 64: $244-246$. 